\title{
Metabolic rates of swimming Humboldt penguins
}

\author{
Guillermo Luna-Jorquera ${ }^{1, *}$, Boris M. Culik ${ }^{2}$ \\ ${ }^{1}$ Universidad Católica del Norte, Larrondo 1281 Coquimbo, Chile \\ ${ }^{2}$ Institut für Meereskunde, Düsternbrooker Weg 20, 24105 Kiel, Germany
}

\begin{abstract}
As one of the elements for a model on the food requirements of Humboldt penguins Spheniscus humboldti we determined, via gas respirometry, metabolic rates while swimming and resting in water. During rest in water at $19^{\circ} \mathrm{C}$ Humboldt penguins (mean body mass $3.6 \mathrm{~kg}$ ) required $5.95 \mathrm{~W} \mathrm{~kg}^{-1}$. This corresponds to a thermal conductance in water of $0.2975 \mathrm{~W}\left(\mathrm{~kg}^{\circ} \mathrm{C}\right)^{-1}\left(\right.$ at $T_{\mathrm{a}} 19^{\circ} \mathrm{C}$ and assuming a $T_{\mathrm{b}}$ of $39^{\circ} \mathrm{C}$ ). When swimming in a $20 \mathrm{~m}$ long channel, metabolism rose from $8 \mathrm{~W} \mathrm{~kg}^{-1}$ at a speed of $0.6 \mathrm{~ms}^{-1}$ to $23.1 \mathrm{~W} \mathrm{~kg}^{-1}$ at $2.2 \mathrm{~m} \mathrm{~s}^{-1}$. Transport costs (the cost to move $1 \mathrm{~kg}$ of body mass over a distance of $1 \mathrm{~m}$ ) reached a minimum at $1.4 \mathrm{~ms}^{-1}$ with $8.1 \mathrm{~J}(\mathrm{~kg} \mathrm{~m})^{-1}$, which corresponds to $0.89 \mathrm{~J}$ $(\mathrm{Nm})^{-1}$. We corrected for acceleration and deceleration in the channel to determine transport costs of free-ranging Humboldt penguins travelling at sea, which were calculated as $7 \mathrm{~J}(\mathrm{~kg} \mathrm{~m})^{-1}(0.71 \mathrm{~J}$ $\left.[\mathrm{Nm}]^{-1}\right)$, at $1.7 \mathrm{~m} \mathrm{~s}^{-1}$. Birds feeding chicks need to balance the costs of either (1) returning to the breeding island for the night and travelling back to the feeding grounds in the morning or (2) incurring increased thermoregulatory costs associated with resting at sea overnight. Simple calculations show that at water temperatures of $19^{\circ} \mathrm{C}$ we expect Humboldt penguins to show a tendency to remain at sea overnight if foraging areas are $>4 \mathrm{~km}$ from their island. In colder waters $\left(12^{\circ} \mathrm{C}\right)$, this distance increases to $>9 \mathrm{~km}$. Using previously published data on at-sea activity of Humboldt penguins, we found that foraging costs during chick rearing amount to $340 \mathrm{~g}$ anchovies $\mathrm{d}^{-1}$. Finally, we present a general model to convert Humboldt penguin activity data at sea to food requirements.
\end{abstract}

KEY WORDS: Oxygen consumption $\cdot$ Resting metabolic rate $\cdot$ Swimming energetics $\cdot$ Swimming speed · Cost of transport · Aerobic dive limit · Food requirements · Modelling

Resale or republication not permitted without written consent of the publisher

\section{INTRODUCTION}

Humboldt penguins Spheniscus humboldti are distributed between 5 and $42^{\circ} \mathrm{S}$ along the Pacific coast of South America and have recently been classified as vulnerable, the population remaining at low levels (ca 13000 birds) since the early 1980s (Ellis et al. 1998). The factors preventing a recovery to higher population densities are presumably a shortage of prey due to over-fishing by commercial anchovy Engraulis ringens and sardine Sardinops sagas fisheries, unfavourable oceanic conditions such as repeated small-scale ENSO (El Niño Southern Oscillation) in the early 1990s and a major ENSO event in 1997-98, marine pollution, and other deleterious anthropogenic influences (Culik et

*E-mail: gluna@coquimbo.cecun.ucn.cl al. 1998). These factors are also acting on Humboldt penguins at Pan de Azúcar National Park $\left(26^{\circ} \mathrm{S}\right.$, $70^{\circ} \mathrm{W}$ ), one of the most important breeding colonies for this species in northern Chile, with a population of 1750 individuals in 1995 (Ellis et al. 1998).

Although the Humboldt penguin was, until recently, thought to be a sedentary species, recent evidence has shown that the birds are capable of migrating considerable distances to avoid unfavourable climatic conditions or in search of prey during an ENSO event (Culik \& Luna-Jorquera 1997a, Culik et al. 2000). Even in normal reproductive years, Humboldt penguins from Pan de Azúcar Island search routinely within a radius of 35 $\mathrm{km}$ around their breeding island to find food for themselves and their chicks (Culik \& Luna-Jorquera 1997b, Culik et al. 1998).

The exact nutritional requirements of Humboldt penguins, i.e. the amount of energy and food required 
per day, are to date unknown. This, however, is a crucial factor in conservation efforts, since it enables the calculation of the food requirements of entire colonies and thus a comparison with other fish consumers and commercial fisheries. Because penguins are highly adapted to life in the marine environment and spend a large proportion of their time at sea, one important parameter for the calculation of daily nutritional needs is the amount of energy expended whilst at sea.

Here we present the results of a study conducted to determine the metabolic rate of Humboldt penguins (1) resting in water and (2) swimming in a $20 \mathrm{~m}$ long channel at various, voluntarily chosen speeds. We used our results to (1) calculate the typical energy requirements of Humboldt penguins during swimming (travelling and foraging), (2) estimate their aerobic dive limit, (3) compare these results with data from other penguin species and (4) estimate food requirements of foraging Humboldt penguins during the reproductive season.

\section{MATERIALS AND METHODS}

Birds. Three adult non-breeding Humboldt penguins were captured on December 19, 1994, at Pan de Azúcar National Park under supervision and by license of Corporación Nacional Forestal (CONAF, IIIa Región, Copiapó, Chile). Birds were caught by hand in their burrows after administration of $0.25 \mathrm{ml}$ ketamine hydrochloride (Ketavet, Parke-Davis GmbH, Berlin, Germany) to tranquillise them (Luna-Jorquera et al. 1996). The birds were held in covered individual $70 \times$ $60 \times 70 \mathrm{~cm}$ cages and rapidly transported at night by car to Antofagasta (ca $400 \mathrm{~km}$ ) in order to avoid overheating and excessive stress. Approximately $6 \mathrm{~h}$ after capture, the birds were transferred to an outdoor pen located $200 \mathrm{~m}$ from the coast in the coastal desert at the Instituto de Investigaciones Oceanológicas, Universidad de Antofagasta, Chile.

In the pen, the penguins were fed daily ad libitum at 18:00 to 19:00 h local time with anchovies or sardines, a multi-vitamin and calcium supplement being administered with the fish. The birds were individually recognizable and had free access to a $1 \mathrm{~m}$ deep pool, filled with seawater, which was changed daily. The birds were examined occasionally by a veterinarian and were considered in good health. Experiments in the swim channel were initiated after an acclimation time of $22 \mathrm{~d}$ and were conducted in the mornings between 09:00 and 11:00 $\mathrm{h}$ and afternoons between 16:00 and 18:00 h. During experiments, mean body mass of the birds was $3.6 \mathrm{~kg}$, with a range of 2.7 to $4.5 \mathrm{~kg}$. All birds were released at the capture site after termination of the experiments in February 1995.
Swim channel. To determine the energy requirements of Humboldt penguins swimming underwater, we constructed and operated a swim channel described by Culik \& Wilson (1991, see their schematic of the experimental setup), and modified by Culik et al. (1996) and Allers \& Culik (1997). In brief, the swim channel consisted of a $20 \mathrm{~m}$ long $\mathrm{U}$-shaped metal sheet (zinc-plated) construction 0.88 to $0.92 \mathrm{~m}$ wide and $0.77 \mathrm{~m}$ deep, pre-built in interlocking, $1.25 \mathrm{~m}$ long segments. This construction was immersed into a $20 \times 5 \mathrm{~m}$ pool filled with seawater and located at the Instituto de Investigaciones Oceanológicas. Because the depth of the pool varied from 1 to $1.5 \mathrm{~m}$, the channel was suspended at the top of the pool and equilibrated to avoid any inclination. The channel was covered ca $5 \mathrm{~cm}$ below the water surface with transparent polyvinylchloride (PVC) sheets (5 $\mathrm{mm}$ thick), bolted to the metal to prevent the penguins from surfacing and breathing at localities other than in the respiration chambers. Water in the pool had to be replaced every $2 \mathrm{~d}$ because of contamination with excreta and algae. To prevent rapid rising of water temperature due to solar irradiation, the pool was covered with black netting (mesh width $3 \mathrm{~cm}$ ) installed $1 \mathrm{~m}$ above the pool.

Respirometry. During experiments, penguins could only breathe in respiration chambers partially immersed at both ends of the channel and thus sealed from outside air. Respiration chambers (A and B) were made of transparent PVC with an air volume of approx. 52 1. Each chamber received outside air via a $37 \times 1 \mathrm{~cm}$ tube (perforated at $15 \mathrm{~mm}$ intervals with $3 \mathrm{~mm}$ holes). Gas mixing in the chamber was additionally achieved via a 12 V ventilator (Truma, Putzbrunn, Germany) with directable air inlets and outlets, yielding a turnover rate of $30 \mathrm{l} \mathrm{s}^{-1}$. Air from the chambers was cleared (negative pressure) at a rate of $501 \mathrm{~min}^{-1}$ using 2 seawater-resistant pumps (MC4, Vacuubrand, Wertheim, Germany) and fed directly to the laboratory via gas-impermeable tubing $(9.5 \mathrm{~mm}$ diameter, Tygon, Norton, USA). A 31 flask was installed in the outflow tube of the chambers to reduce pressure variations from the pump, collect condensation and act as a silencer.

In the laboratory, gas flow from each chamber was measured using 1 of 2 mass flow meters (MAS 3015, Kobold, Hofheim, Germany) and a subsample was dried (Drierite, Aldrich Chemicals) and passed into 1 of 2 paramagnetic oxygen analysers (OXYGOR) and subsequently into an infrared carbon dioxide analyser (UNOR, both Maihak, Hamburg, Germany). Calibration of the gas analysers was repeated daily using $99.995 \%$ pure $\mathrm{N}_{2}$ and $\mathrm{CO}_{2}$ gases (Messer Griesheim, Hamburg, Germany), as well as ambient air $(20.95 \%$ $\mathrm{O}_{2}$ and $0.03 \% \mathrm{CO}_{2}$ ). Calibration gases were diluted with ambient air with the aid of a Wösthoff pump 
SA27/3 (Wösthoff, Bochum, Germany) to $19.90 \% \mathrm{O}_{2}$ and $1.03 \% \mathrm{CO}_{2}$. During the experiments, $\mathrm{O}_{2}$ and $\mathrm{CO}_{2}$ concentrations in the respiration chambers remained above $20 \%$ and below $1 \%$, respectively. Calibration checks with ambient air were made before and after each experiment. Absorption of $\mathrm{CO}_{2}$ by seawater during the experiment was assumed to be negligible (Williams 1989) and estimated to amount to a maximum of $0.015 \% \mathrm{~min}^{-1}$ (Liss \& Merlivat 1986, A. Körtzinger pers. comm.). Data from the 3 analysers and the 2 flow meters were sampled every $2 \mathrm{~s}$ by an IBMcompatible 386SX computer (Chicony, Hamburg, Germany) fitted with an analogue-digital conversion card and using purpose-made software (resolution: 0.01\% $\mathrm{O}_{2}$ and $\mathrm{CO}_{2}$ ).

Recovery rates for the whole system (including mass flow meter, analysers, A/D converter, and computational techniques) were determined by pumping known volumes of nitrogen (99.995\% pure) into the respiration chambers with a standard gas meter. We obtained a recovery rate of $99.6 \%(n=3)$, which compares well to the $99.8 \%( \pm 5 \%, \mathrm{n}=43)$, previously determined by Allers \& Culik (1997) for the same setup and equipment.

Penguin behaviour. Prior to the initiation of experiments, penguins were trained 3 times (during 3 consecutive days for at least $2 \mathrm{~h}$ ) in the pool. The first time a bird was in the channel, 2 people were required to ensure that it found the respiration chamber after its first dive. The penguins rapidly adapted to the new situation and found a respiration chamber within 1 to 2 min after the beginning of an experiment and subsequently explored the channel, presumably to find an exit, thereby swimming up and down, from one chamber to the other. In the channel the penguins were undisturbed and swam voluntarily at their preferred speeds. The typical duration of experiments was $1 \mathrm{~h}$, depending on the performance of the penguins. In general, the birds were co-operative and adopted a regular swimming pattern.

The activity of the birds in the swim channel was monitored from an observation seat $3 \mathrm{~m}$ above the ground. The behaviour and position of the birds in the channel were recorded in real time using a Husky Hunter II field computer (Husky, Coventry, England) and specially designed software. Each key on the computer was associated with a particular type of behaviour or position of the bird. Each time one of the keys was pressed, time (0.1 s resolution) as well as the key just pressed were stored. Each type of behaviour ended when a new type of behaviour was recorded, while positional information (the swim channel was marked at $1 \mathrm{~m}$ intervals) was associated with the exact time at which it was recorded. The data obtained were saved in individual files for each experiment and later analysed using specially designed software to obtain: (1) swimming speed, (2) distance swum, (3) dive duration and (4) surface duration for each individual diving event. If a bird turned around between 2 markers, no speed was computed until the penguin swam again in a straight line.

Activity and respirometry data were individually matched for each interdive interval. Before further analysis, the complete data set was filtered to include only periods during which the birds either rested in one of the chambers or swam for a minimum of $18 \mathrm{~m}$ through the channel, including occasional turns, and then surfaced and recovered quietly. Prior to surfacing in a respiration chamber, the birds had been absent from that chamber for a minimum of $10 \mathrm{~s}$, a sufficient delay to separate individual dive + surfacing events. All dives followed by shivering, unrest and preening were deleted from the analysis. We conducted a total of 216 experiments with the 3 penguins and obtained 688 individually analysed dives or dive series in the channel.

Oxygen consumption. Oxygen consumption of penguins in the respiration chambers was calculated for every $2 \mathrm{~s}$ interval using the formula of Woakes \& Butler (1983) as modified by Culik et al. (1990), which accounts for analyser drift. Oxygen consumption was corrected for respiratory quotient (Withers 1977) and summed only if values were above a threshold of $1 \mathrm{ml}$ $\mathrm{s}^{-1}$ for 3 consecutive measurements. This ensured that 'noise' in the apparatus was not recorded when birds were absent from the chambers.

According to Culik et al. (1996), penguin oxygen consumption in the chambers during surface time reflects oxygen consumption while swimming (and holding breath) just prior to surfacing, plus oxygen consumption during the current recovery period. The duration of recovery is defined as the time required for elevated $\mathrm{O}_{2}$-consumption rates after a dive series to return to resting levels (here, resting in water; Castellini et al. 1992). The total amount of oxygen consumed during the recovery period after a dive series was therefore divided by the time spent holding breath plus the time of recovery to obtain the rate of $\mathrm{O}_{2}$ consumption $\left(\mathrm{ml} \mathrm{O}_{2} \mathrm{~s}^{-1}\right)$ for the entire event (dive + recovery). The corresponding power input $(P)$ should reflect the energy expenditure of birds travelling or foraging at sea.

In order to analyse energy requirements of diving penguins with respect to swimming speed, $P$ was averaged for $0.1 \mathrm{~m} \mathrm{~s}^{-1}$ speed classes (e.g. power data obtained at mean swimming speeds between 0.45 and $0.54 \mathrm{~m} \mathrm{~s}^{-1}$ were summarised into the $0.5 \mathrm{~m} \mathrm{~s}^{-1}$ speed class, and so on). All data were statistically treated using SYSTAT for Windows. Data were tested for normality and homoscedasticity before applying paramet- 
ric or non-parametric tests as appropriate (Zar 1984). Means are presented \pm standard error (SE).

\section{RESULTS}

\section{Resting metabolic rate}

After a period of $22 \mathrm{~d}$ of acclimation to captivity, the penguins had habituated well to human handling, voluntarily accepted being hand-fed and did not show evidence of stress when approached. During several experiments in the swim channel, the 3 Humboldt penguins were observed to rest for more than $10 \mathrm{~min}$ in one of the respiration chambers, floating quietly at the surface. Mean energy expenditure for rest in water (Table 1) did not significantly differ between birds (ANOVA, $F=0.010 ; \mathrm{p}=0.98$ ). Consequently, all data were pooled, yielding a mean resting oxygen consumption in water of $1.09 \pm 0.07 \mathrm{ml} \mathrm{O}_{2} \mathrm{~s}^{-1}$. Respiratory quotient $(\mathrm{RQ})$ was $0.78 \pm 0.05$, resulting in a conversion factor of $20 \mathrm{~J} \mathrm{ml}^{-1} \mathrm{O}_{2}$ to convert to $\mathrm{W} \mathrm{kg}^{-1}$ (Eckert 1993, Schmidt-Nielsen 1993). Metabolic rate of Humboldt penguins resting in water $\left(\mathrm{RMR}_{\mathrm{water}}\right)$ therefore amounts to $5.95 \mathrm{~W} \mathrm{~kg}^{-1}\left(\mathrm{n}=20\right.$ measurements, $\left.T_{\text {water }}=19 \pm 1.0^{\circ} \mathrm{C}\right)$.

\section{Swimming metabolism}

Typically, Humboldt penguins swam from one end of the channel to the other, accelerating and decelerating

Table 1. Spheniscus humboldti. Mean and standard error (SE) of oxygen consumption of 3 Humboldt penguins at rest in the swim channel. Grand mean and respective SE were obtained by data pooling (ANOVA, $\mathrm{p}>0.05$ )

\begin{tabular}{|lccr|}
\hline Penguin & $\mathrm{ml} \mathrm{O}_{2} \mathrm{~s}^{-1}$ & Body mass $(\mathrm{kg})$ & $\mathrm{N}$ \\
\hline $\mathrm{A}$ & $1.17(0.105)$ & $3.4(0.380)$ & 7 \\
$\mathrm{~B}$ & $1.31(0.104)$ & $4.1(0.125)$ & 6 \\
$\mathrm{C}$ & $0.89(0.093)$ & $3.4(0.110)$ & 7 \\
Grand mean & $1.090(0.070)$ & $3.6(0.126)$ & 20 \\
\hline
\end{tabular}

in the first and last $4 \mathrm{~m}$, while maintaining a relatively constant speed over the middle section (12 m). Swimming speeds of the birds ranged from 0.6 to $2.2 \mathrm{~m} \mathrm{~s}^{-1}$ with a mean of $1.12 \pm 0.01 \mathrm{~m} \mathrm{~s}^{-1}$ ( $\mathrm{n}=688$ measurements; Table 2). Swimming speeds were significantly different between birds (ANOVA, $F=48.228$; $\mathrm{p}<$ 0.001). Penguins did not always surface immediately after swimming from one end of the channel to the other, but no differences were detected between individual swimming distances (ANOVA, $F=2.309 ; \mathrm{p}=$ $0.100)$, which averaged $19.74 \pm 0.18 \mathrm{~m}$ ( $\mathrm{n}=688$ measurements).

Mean power requirements $\left(P_{\text {dive }}\right.$ in $\left.\mathrm{W} \mathrm{kg}^{-1}\right)$ for the entire dive + surface cycle were analysed with respect to speed. Data of the 3 penguins were modelled using a third-degree polynomial (Culik et al. 1996):

$$
P_{\text {dive }}=a v^{3}+b v^{2}+c v+\mathrm{RMR}_{\text {water }}
$$

where $v$ is swimming speed $\left(\mathrm{m} \mathrm{s}^{-1}\right)$. The corresponding parameters $(a, b, c)$ were computed for each bird individually and are given in Table 3 . We found that power input did not significantly differ between penguins swimming at the same speed (ANOVA, $F=1.17 ; \mathrm{p}=$ 0.323). Data were therefore pooled and power input modelled to obtain a general equation for Humboldt penguins (Table 3). The corresponding curve fit is shown in Fig. 1. When swimming, the mean $P$ of all 3 Humboldt penguins averaged $9.05 \pm 0.11 \mathrm{~W} \mathrm{~kg}^{-1}$ ( $\mathrm{n}=688$ measurements; Table 2). However, power requirements varied significantly between speed classes (ANOVA, $F=32.85$; $\mathrm{p}<0.001$ ), ranging from $8.0 \pm 0.47 \mathrm{~W} \mathrm{~kg}^{-1}$ at $0.6 \mathrm{~m} \mathrm{~s}^{-1}$ to $23.1 \pm 2.65 \mathrm{~W} \mathrm{~kg}^{-1}$ at $2.2 \mathrm{~m} \mathrm{~s}^{-1}$.

The polynomial equation used above also allows modelling of cost of transport (COT in $\mathrm{J}[\mathrm{kg} \mathrm{m}]^{-1}$ ), which is obtained by dividing power $\left(\mathrm{W} \mathrm{kg}^{-1}\right.$ or $\mathrm{J} \mathrm{s}^{-1}$ $\mathrm{kg}^{-1}$ ) by speed $\left(\mathrm{m} \mathrm{s}^{-1}\right)$ :

$$
\mathrm{COT}=\left(a v^{3}+b v^{2}+c v+\mathrm{RMR}_{\text {water }}\right) / v
$$

COT is the amount of energy required to transport $1 \mathrm{~kg}$ of body mass over a distance of $1 \mathrm{~m}$ (Schmidt-Nielsen 1993). Videler \& Nolet (1990) suggested expressing

Table 2. Spheniscus humboldti. Mean swimming speed and distance swam of the 3 Humboldt penguins used in the swim chan-

\begin{tabular}{|c|c|c|c|c|c|c|c|}
\hline Penguin & $\begin{array}{l}\text { Swimming speed } \\
\left(\mathrm{m} \mathrm{s}^{-1}\right)\end{array}$ & SE & $\begin{array}{l}\text { Distance swam } \\
\text { (m) }\end{array}$ & SE & $\begin{array}{l}\text { Dives } \\
\text { (n) }\end{array}$ & $\begin{array}{l}\text { Power } \\
\left(\mathrm{W} \mathrm{kg}^{-1}\right)\end{array}$ & $\mathrm{SE}$ \\
\hline A & 1.11 & 0.020 & 19.9 & 0.29 & 289 & 9.26 & 0.195 \\
\hline B & 0.99 & 0.014 & 20.1 & 0.36 & 173 & 8.38 & 0.170 \\
\hline $\mathrm{C}$ & 1.25 & 0.014 & 19.2 & 0.30 & 226 & 9.29 & 0.211 \\
\hline Mean & 1.12 & 0.011 & 19.7 & 0.18 & & 9.05 & 0.116 \\
\hline
\end{tabular}
nel experiments. SE is standard error 
Table 3. Parameters used to calculate power input $\left(\mathrm{W} \mathrm{kg}^{-1}\right)$ of 3 Humboldt penguins while swimming in a channel. Power input $(P)$ was calculated according to Culik et al. (1996) and is best described by $P=a v^{3}+b v^{2}+c v+\mathrm{RMR}_{\text {water, }}$ where $v$ is swimming speed $\left(\mathrm{m} \mathrm{s}^{-1}\right)$ and $\mathrm{RMR}_{\text {water }}$ is resting metabolic rate. Power input is the power required over the entire 'dive + surface' cycle. Differences between birds were not significant $(\mathrm{p}=0.323)$

\begin{tabular}{|lccccc|}
\hline Penguin & $a$ & $b$ & $c$ & $\mathrm{RMR}_{\text {water }}$ & $\mathrm{r}^{2}$ \\
\hline A & 3.150 & -5.990 & 5.150 & 6.88 & 0.93 \\
B & 3.612 & -6.210 & 5.790 & 6.39 & 0.93 \\
C & 3.451 & -6.371 & 5.643 & 5.24 & 0.90 \\
All birds & 3.541 & -6.382 & 5.841 & 5.95 & 0.94 \\
& & & & & \\
\hline
\end{tabular}

COT as a dimensionless variable $\left(\mathrm{J}[\mathrm{N} \mathrm{m}]^{-1}\right)$, which is obtained by dividing COT (in $\mathrm{J}\left[\mathrm{kg} \mathrm{m}^{-1}\right.$ ) by earth acceleration $\left(9.81 \mathrm{~m} \mathrm{~s}^{-1}\right)$. Here we prefer to use $\mathrm{J}(\mathrm{kg}$ $\mathrm{m})^{-1}$ to simplify comparisons with the literature. COT in Humboldt penguins averaged $9.01 \pm 0.09 \mathrm{~J}(\mathrm{~kg} \mathrm{~m})^{-1}$ $(\mathrm{n}=688)$ and ranged from $13.41 \pm 0.06 \mathrm{~J}(\mathrm{~kg} \mathrm{~m})^{-1}$ at 0.6 $\mathrm{m} \mathrm{s}^{-1}(\mathrm{n}=7)$ to a minimum of $8.10 \pm 0.03 \mathrm{~J}(\mathrm{~kg} \mathrm{~m})^{-1}$ at $1.4 \mathrm{~m} \mathrm{~s}^{-1}(\mathrm{n}=22)$. COT (Fig. 1) were significantly different (ANOVA, $F=1336.65 ; \mathrm{p}<0.001$ ) between speed classes, being maximal at speed classes $<0.9$ and $>2.0 \mathrm{~m} \mathrm{~s}^{-1}$ (Tukey test, $\mathrm{p}<0.05$ ).

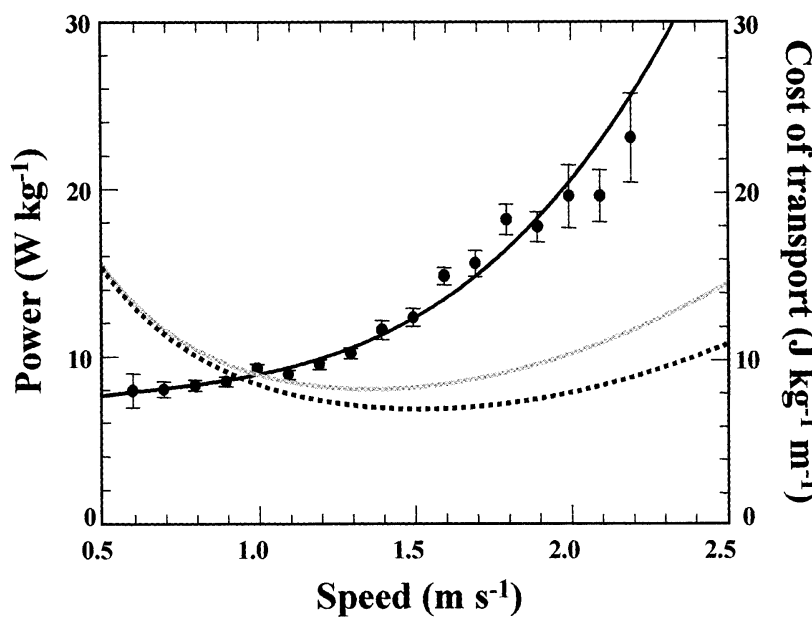

Fig. 1. Spheniscus humboldti. Power input ( $\left.\mathrm{W} \mathrm{kg}^{-1}\right)$ in Humboldt penguins swimming at different speeds. Parameters of the equation describing the curve fit are given in Table 3 . Bars show standard error of the means. Cost of transport (COT) of penguins in the channel $\left(\mathrm{J}[\mathrm{kg} \mathrm{m}]^{-1}\right.$, grey line) were fitted using COT $=\left(3.541 v^{3}-6.382 v^{2}+5.841 v+5.95\right) / v(\mathrm{n}=$ $\left.688, \mathrm{r}^{2}=0.93\right)$. The dotted line is $\mathrm{COT}_{\text {cor }}$ corrected for acceleration and deceleration in the swim channel (see more details in the text). The equation describing this curve fit is $\mathrm{COT}_{\text {cor }}=\left(2.954 v^{3}-6.354 v^{2}+5.818 v+5.95\right) / v\left(\mathrm{n}=688, \mathrm{r}^{2}=0.92\right)$

\section{DISCUSSION}

\section{Resting metabolic rate in water}

$\mathrm{RMR}_{\text {water }}$ of Humboldt penguins in the channel (5.95 $\mathrm{W} \mathrm{kg}^{-1}$ or $1.09 \mathrm{ml} \mathrm{O} \mathrm{s}^{-1}$; water temperature $\left[T_{\text {water }}\right]=19^{\circ} \mathrm{C}$ ) compares well to the value reported by Butler \& Woakes (1984), who determined $0.993 \mathrm{ml} \mathrm{O}_{2}$ $\mathrm{s}^{-1}$ for the same species at a water temperature of $18^{\circ} \mathrm{C}$. Assuming a BMR (basal metabolic rate) for Humboldt penguins of $2.83 \mathrm{~W} \mathrm{~kg}^{-1}$ (Drent \& Stonehouse 1971), $\mathrm{RMR}_{\text {water }}$ corresponds to ca $2.1 \times \mathrm{BMR}$. However, when compared to $\mathrm{RMR}_{\text {air }}$ of $3.8 \mathrm{~W} \mathrm{~kg}^{-1}$ (measured during the active phase in normally fed Humboldt penguins within their thermoneutral zone; Luna-Jorquera 1997), $\mathrm{RMR}_{\text {water }}$ is only $1.6 \times \mathrm{RMR}_{\text {air }}$. This is quite low, as Bethge et al. (1997) reported that in little penguins Eudyptula minor $\mathrm{RMR}_{\text {water }}$ at $10^{\circ} \mathrm{C}$ is $2.6 \times \mathrm{RMR}_{\text {air }}$. Similarly, Culik \& Wilson (1991) reported that mean $\mathrm{RMR}_{\text {water }}$ of Adélie penguins $\left(4^{\circ} \mathrm{C}\right)$ amounts to $2.2 \times \mathrm{RMR}_{\text {air }}$. Rather than being species specific, however, these differences can probably be attributed to the effects of temperature and thermal insulation (Stahel \& Nicol 1982). Mean water temperature around Pan de Azúcar Island, measured by free-ranging Humboldt penguins equipped with data-loggers (Luna-Jorquera \& Culik 1999), was $14.6^{\circ} \mathrm{C}$, but at the surface, water temperature ranged between 12 and $18^{\circ} \mathrm{C}$, to which the effect of direct solar irradiation has to be added. Consequently, we propose that the value for $\mathrm{RMR}_{\text {water }}$ reported here is applicable to the field situation in surface waters around Pan de Azúcar Island (2609' S), during warm days.

\section{Energy requirements during swimming}

Culik et al. (1996) described 3 different methods for the calculation of $\mathrm{O}_{2}$-consumption rates from experiments conducted in a channel. Because our objective in the present study was to obtain data on swimming energetics applicable to Humboldt penguins in the wild, we will discuss only the energy consumption during the entire surface + dive cycle.

The swim channel method both ensures controlled experimental conditions and allows voluntary diving by the penguins. However, artificial conditions during the experiments and the necessity for the birds to accelerate and decelerate repeatedly alter their behaviour and increase their energetic demands. For these reasons Culik et al. (1994a) suggested that swim-channel data be corrected for this effect (see below). However, swimming speed in the channel cannot be corrected. The penguins in the channel swam at an average speed of only $1.1 \mathrm{~m} \mathrm{~s}^{-1}$, which is $35 \%$ slower than the mean of $1.7 \mathrm{~m} \mathrm{~s}^{-1}$ observed in travelling Hum- 
boldt penguins at sea (Luna-Jorquera \& Culik 1999). However, slow speeds were also observed by Culik et al. (1994a) and Bethge et al. (1997), in pygoscelid and little penguins during similar experiments. According to these authors, gentoo penguins Pygoscelis papua, Adélie penguins Pygoscelis adeliae and chinstrap penguins $P$. antarctica observed in a $21 \mathrm{~m}$ long swim channel swam 21, 32 and $35 \%$ slower than measured in the wild, respectively, whereas little penguins swam $80 \%$ slower.

The only data published on transport costs of Humboldt penguins during underwater swimming stem from Hui (1988). He determined a minimum COT of $13.4 \mathrm{~J}(\mathrm{~kg} \mathrm{~m})^{-1}$ for swimming speeds ranging from 0.5 to $1.26 \mathrm{~m} \mathrm{~s}^{-1}$, a value which is $47 \%$ higher than ours for the same speed range. This discrepancy can be attributed to the methodology employed by Hui (1988) - a test cage pushed through the water by a boat - and the stress imposed on the birds because of the involuntary nature of the exercise. Nagy et al. (1984), using doubly labelled water and a speed meter attached to free-ranging African penguins Spheniscus demersus, and RMR-values derived from allometric equations, determined a mean COT of $15.5 \mathrm{~J}(\mathrm{~kg} \mathrm{~m})^{-1}$ at speeds of $2.0 \mathrm{~m} \mathrm{~s}^{-1}$, or $55 \%$ higher than our measurement at the same speed. Besides additional COT imposed on the device-equipped birds by the frictional drag of the speed meters (cf. Culik et al. 1994b), the use of an allometric equation as opposed to actually measured values of $\mathrm{RMR}_{\mathrm{water}}$ may have led to the high estimate of swimming metabolism by Nagy et al. (1984).

During our experiments, Humboldt penguins swimming in the channel had to accelerate and decelerate once every $20 \mathrm{~m}$, which they are unlikely to do in the wild (except while foraging), thereby incurring higher energetic costs (Culik et al. 1994a). In order to compensate for more than one initial acceleration, and to estimate the energetic costs incurred by Humboldt penguins during travelling, the physical energy necessary for subsequent acceleration and deceleration $\left(P a, \mathrm{~W} \mathrm{~kg}{ }^{-1}\right)$ prior to surfacing was subtracted from $P_{\text {dive. }} . P a=v^{3}(m f S)^{-1}$, where $v$ is swimming speed in $\mathrm{m} \mathrm{s}^{-1}, m$ is muscle efficiency ( $m=0.25$ according to Schmidt-Nielsen 1993), $f$ is flipper efficiency ( $f=0.4$ according to Oehme \& Bannasch 1989), and $S$ is the distance swam. The corrected data set was curve-fitted with a third-degree polynomial function to estimate corrected power input $\left(P_{\text {cor }}\right)$ :

$P_{\text {cor }}=2.954 v^{3}-6.354 v^{2}+5.818 v+\mathrm{RMR}_{\text {water }}\left(\mathrm{r}^{2}=0.92\right)$

where $V$ is swimming speed $\left(\mathrm{m} \mathrm{s}^{-1}\right)$. Using $\mathrm{P}_{\text {cor, }}$ we found that minimum corrected transport costs (COTcor) are $6.81 \pm 0.03(\mathrm{n}=26) \mathrm{J}(\mathrm{kg} \mathrm{m})^{-1}$ at a swimming speed of $1.5 \mathrm{~m} \mathrm{~s}^{-1}$. This is $19 \%$ lower than minimum COT obtained from penguins swimming in the channel.

Minimum $\mathrm{COT}_{\text {cor }}$ of Humboldt penguins (at $1.5 \mathrm{~m}$ $\mathrm{s}^{-1}$ ) were between those of Adélie penguins $(4.9 \mathrm{~J}$ $[\mathrm{kg} \mathrm{m}]^{-1}$ at $\left.2.2 \mathrm{~m} \mathrm{~s}^{-1}\right)$ and gentoo penguins $(7.6 \mathrm{~J}[\mathrm{~kg}$ $\mathrm{m}^{-1}$ at $1.8 \mathrm{~m} \mathrm{~s}^{-1}$ ) (Culik et al. 1994a) (Table 4). In the much smaller little penguin, Bethge et al. (1997) found minimum COT of $11.1 \mathrm{~J}(\mathrm{~kg} \mathrm{~m})^{-1}$ at $1.8 \mathrm{~m} \mathrm{~s}^{-1}$. Although minimum COT in the channel occured at $1.5 \mathrm{~m} \mathrm{~s}^{-1}$, we measured that Humboldt penguins in the wild prefer to travel at $1.7 \mathrm{~m} \mathrm{~s}^{-1}$ (Luna-Jorquera \& Culik 1999). Mean $\mathrm{COT}_{\text {cor }}$ in travelling $\left(1.7 \mathrm{~m} \mathrm{~s}^{-1}\right)$ Humboldt penguins is $7.0 \pm 0.05 \mathrm{~J}(\mathrm{~kg} \mathrm{~m})^{-1}$, or only $3 \%$ higher than the minimum at $1.5 \mathrm{~m} \mathrm{~s}^{-1}$. Because in the field Humboldt penguins sometimes travel much faster, reaching speeds $>4.0 \mathrm{~m} \mathrm{~s}^{-1}$ (Luna-Jorquera \& Culik 1999), we suggest that Eq. (3) be employed to calculate the corresponding energetic requirements at sea, if the birds' actual travelling speeds are known.

Table 4. Minimum power input $\left(P_{\text {cor }}\right)$ and cost of transport (COT) calculated by assuming only one acceleration and subsequent sustained swimming speeds (Culik et al. 1994a), and aerobic dive limits (ADL) of penguins calculated from energy requirements during swimming. Sources: (1) Bethge et al. (1997), (2) Culik et al. (1994a), (3) Nagy et al. (1984), (4) Hui (1988), (5) Butler \& Woakes (1984), and (6) this study

\begin{tabular}{|c|c|c|c|c|c|c|}
\hline Species & $\begin{array}{l}\text { Body mass } \\
(\mathrm{kg})\end{array}$ & $\begin{array}{c}P_{\text {cor }} \\
\left(\mathrm{W} \mathrm{kg}^{-1}\right)\end{array}$ & $\begin{array}{c}\mathrm{COT} \\
\left(\mathrm{J}[\mathrm{kg} \mathrm{m}]^{-1}\right)\end{array}$ & $\begin{array}{l}\text { Speed } \\
\left(\mathrm{m} \mathrm{s}^{-1}\right)\end{array}$ & $\begin{array}{l}\mathrm{ADL} \\
\text { (s) }\end{array}$ & Source \\
\hline Eudyptula minor & 1.2 & 20.0 & 11.1 & 1.8 & 44 & 1 \\
\hline Pygoscelis antarctica & 3.8 & 8.9 & 3.7 & 2.4 & 130 & 2 \\
\hline$P$. adeliae & 4.0 & 10.8 & 4.9 & 2.2 & 110 & 2 \\
\hline P. papua & 5.5 & 13.7 & 7.6 & 1.8 & 93 & 2 \\
\hline Spheniscus demersus & 3.2 & 31.0 & 15.5 & 2.0 & 38 & 3 \\
\hline S. humboldti & 3.8 & $8.1-14.9$ & 13.4 & $0.5-1.26$ & - & 4 \\
\hline S. humboldti & 4.6 & - & - & - & 136 & 5 \\
\hline S. humboldti & 3.6 & 10.2 & 6.8 & 1.5 & 116 & 6 \\
\hline
\end{tabular}




\section{Aerobic dive limits}

Prior to a dive, penguins store oxygen in arterial and venous blood, muscle tissue and air sacs (Kooyman 1989) and oxygen stores can be calculated from the oxygen-binding capacity of blood and muscle and oxygen saturation prior to a dive (Culik et al. 1994a). Because no data were available for Humboldt penguins, we assume here that their $\mathrm{O}_{2}$ stores are comparable to those of other species. In pygoscelid penguins (mean of $4.4 \pm 0.5 \mathrm{~kg}$; range $=3.8$ to $5.5 \mathrm{~kg}$ ), total oxygen stores amount to $57 \mathrm{ml} \mathrm{kg}^{-1}$ in chinstrap penguins, $58.6 \mathrm{ml} \mathrm{kg}^{-1}$ in Adélie penguins and $63 \mathrm{ml} \mathrm{kg}^{-1}$ in gentoo penguins, with a mean of $59.5 \pm 1.8 \mathrm{ml} \mathrm{kg} \mathrm{k}^{-1}$ (derived from data published by Culik et al. 1994a).

The aerobic dive limit (ADL) is defined as the maximum dive duration prior to which an increase in blood lactic acid concentration occurs (Gentry \& Kooyman 1986). ADL can be estimated from: $\mathrm{ADL}=k \mathrm{OXY} / P$, where $k$ is the conversion factor $\left(20 \mathrm{~J} \mathrm{ml}^{-1} \mathrm{O}_{2}\right.$, see 'Results'), OXY are the total oxygen stores prior to a dive and $P$ is the energy required for swimming. Correspondingly, aerobic dive distance is $\mathrm{ADD}=V \mathrm{ADL}$, where $V$ is swimming speed. Using minimum $P_{\text {cor }}$ determined above (at $1.5 \mathrm{~m} \mathrm{~s}^{-1}$ ) and OXY from pygoscelid penguins, we estimate that Humboldt penguins should be able to dive aerobically for $116 \mathrm{~s}$ and cover a distance of $174 \mathrm{~m}$ within that time, if swimming in a straight line without energy-consuming manoeuvres. This value is consistent with the results obtained using dive recorders in free-ranging Humboldt penguins (Luna-Jorquera \& Culik 1999), which showed that 95\% of all dives were shorter than $90 \mathrm{~s}$. Only $1 \%$ of all dives recorded in the wild exceed the aerobic dive limit calculated here. Our result also compares well with that of Butler \& Woakes (1984), who calculated that Humboldt penguins diving at a rate of $5.46 \mathrm{~W} \mathrm{~kg}^{-1}$ would have an ADL of $136 \mathrm{~s}$, a value only $17 \%$ higher than our estimate.

In a previous study on the foraging behaviour of breeding Humboldt penguins using VHF telemetry (Culik et al. 1998), we calculated the running mean dive and surface duration (Horning 1992) of a series of dives and determined the behavioural aerobic dive limit (bADL). Surprisingly, bADL, i.e. the threshold in dive duration followed by a steep increase in surface pause times, was reached in dives lasting $50 \mathrm{~s}$, or only ca $43 \%$ of ADL determined above. This apparent discrepancy could suggest that oxygen utilisation in foraging birds is only in part governed by metabolic requirements of straight-line swimming (i.e. by $P_{\text {cor }}$ above). Indeed, frequent acceleration and deceleration and manoeuvres required to pursue prey, as well as to investigate foraging areas, and the effects of buoyancy may lead to increased oxygen consumption and per- haps lactate production (Culik et al. 1994a) in wild Humboldt penguins. As a consequence, surface pauses required for the replenishment of oxygen reserves and to ensure metabolic turnover of lactic acid have to be extended in wild birds diving for longer than $50 \mathrm{~s}$.

\section{To remain at sea or to rest on land?}

Humboldt penguins often rest at sea for extended periods. Foraging birds sometimes remain at sea overnight (Culik \& Luna-Jorquera 1997b, Luna-Jorquera \& Culik 1999) and in winter the penguins are capable of migrating as far as $600 \mathrm{~km}$ to the north of their colony, reaching the coast only at intervals of approx. $15 \mathrm{~d}$ (Culik \& Luna-Jorquera 1997a). What are the energetic implications of this behaviour? From RMR-measurements in the channel, thermal conductance in water was calculated as $0.2975 \mathrm{~W}\left(\mathrm{~kg}^{\circ} \mathrm{C}\right)^{-1}$ (at $T_{\mathrm{a}} 19^{\circ} \mathrm{C}$ and assuming a $T_{\mathrm{b}}$ of $39^{\circ} \mathrm{C}$; Drent \& Stonehouse 1971, LunaJorquera et al. 1997), or ca $2 \times$ the calculated thermal conductance $\left(0.15 \mathrm{~W}\left[\mathrm{~kg}{ }^{\circ} \mathrm{C}\right]^{-1}\right)$ below the thermoneutral zone in air (Luna-Jorquera 1997), reflecting the high rate of heat loss in water. From the equation of thermal conductance $\left(\mathrm{C}\right.$, in $\left.\mathrm{W}\left[\mathrm{kg}^{\circ} \mathrm{C}\right]^{-1}\right)$ :

$$
\mathrm{C}=P /\left(T_{\mathrm{b}}-T_{\mathrm{a}}\right)
$$

where $P$ is power input ( $\left.\mathrm{W} \mathrm{kg}^{-1}\right), T_{\mathrm{b}}$ is body temperature $\left({ }^{\circ} \mathrm{C}\right)$ and $T_{\mathrm{a}}$ is ambient or seawater temperature $\left({ }^{\circ} \mathrm{C}\right)$; it is possible to derive $\mathrm{RMR}_{\text {water }}$ at different water temperatures (Schmidt-Nielsen 1993). At the maximum temperatures recorded in surface waters around Pan de Azúcar Island, we estimate that $\mathrm{RMR}_{\text {water }}$ is comparable to the value determined in the channel. However, at water temperatures of $12^{\circ} \mathrm{C}, \mathrm{RMR}_{\text {water }}$ should increase by $35 \%$.

Our field data (Culik \& Luna-Jorquera 1997b, LunaJorquera \& Culik 1999) show that during daylight, penguins swim actively with only short resting periods at the surface. By analogy to African penguins Spheniscus demersus, whose body temperature rises when they swim, and sinks again when they rest at the surface (Wilson \& Grémillet 1996), we would expect thermoregulatory costs in active penguins to be covered by waste heat from locomotion (Hind \& Gurney 1997). However, since Humboldt penguins do not actively forage at night (Luna-Jorquera \& Culik 1999), which is supported by all the evidence currently available for penguins of the genus Spheniscus (see Wilson 1995), we would expect thermoregulatory costs to rise at that time. For birds feeding chicks, the optimal energy solution lies in balancing the costs of either (1) returning to the breeding island for the night and travelling back to the feeding grounds in the morning or (2) incurring 
increased thermoregulatory costs associated with resting at sea overnight.

Assuming a constant seawater temperature of $19^{\circ} \mathrm{C}$, the energetic costs for Humboldt penguins resting at sea correspond to $\mathrm{RMR}_{\text {water }}$ (see above) or ca $77 \mathrm{~kJ} \mathrm{~h}^{-1}$ $\operatorname{bird}^{-1}\left(104 \mathrm{~kJ} \mathrm{~h}^{-1}\right.$ at $\left.12^{\circ} \mathrm{C}\right)$ or $616 \mathrm{~kJ}$ bird ${ }^{-1}$ for an $8 \mathrm{~h}$ night at sea $\left(832 \mathrm{~kJ}\right.$ at $\left.12^{\circ} \mathrm{C}\right)$. During an equivalent period on land a single Humboldt penguin would expend only ca $394 \mathrm{~kJ}$ ( $3.8 \mathrm{~W} \mathrm{~kg}^{-1}$ [RMR on land] $\times$ $3.6 \mathrm{~kg} \times 3600 \mathrm{~s} \times 8 \mathrm{~h}$; Luna-Jorquera 1997). The difference between these 2 values can be translated in terms of distance travelled in order to determine whether a foraging adult would energetically benefit by remaining at sea or returning to land overnight. Since swimming costs are ca $12 \mathrm{~W} \mathrm{~kg}^{-1}$ ( $P_{\text {cor }}$ for typical travelling swim speeds of $1.7 \mathrm{~m} \mathrm{~s}^{-1}$ ), the $222 \mathrm{~kJ}$ difference would allow the penguin to swim for $222000 /(12 \times 3.6)$ or $5138 \mathrm{~s}$, during which time the penguin could travel roughly $8.7 \mathrm{~km}$ in a straight line. This value must be divided by 2 (to and from feeding grounds) in order to derive the approximate range. Thus, at water temperatures of $19^{\circ} \mathrm{C}$, we might expect Humboldt penguins to show a tendency to remain at sea overnight if foraging areas are $4 \mathrm{~km}$ or more distant from the island. In colder waters $\left(12^{\circ} \mathrm{C}\right)$, all other things being equal, birds should decide to return to land if closer than approximately $9 \mathrm{~km}$ to the coast. This approach is obviously simplistic, because it does not take into account parameters such as satiation, prey availability, chick-feeding frequency, or convoluted travelling routes (Culik et al. 1998), but it nevertheless highlights one energetic aspect acting on penguins foraging at sea.

\section{Food requirements during foraging and migration}

In a previous study on the foraging behaviour of Humboldt penguins we used time-depth-speed recorders (MK6, Wildlife Computers), to determine (amongst others parameters) time spent at the surface and underwater and the swimming speed of 12 penguins rearing chicks (Luna-Jorquera \& Culik 1999). Mean speed for travelling and foraging dives were 1.7 and $1.9 \mathrm{~m} \mathrm{~s}^{-1}$, respectively (Luna-Jorquera \& Culik 1999). Porpoising was considered to be negligible. Estimating the energy required for straight-line travelling dives using $P_{\text {cor }}$ above (Eq. 3) yields $12 \mathrm{~W} \mathrm{~kg}^{-1}$, whereas using $P_{\text {dive }}$ (Eq. 1) for foraging dives with naturally occurring stop and go activity and manoeuvres yields $18.3 \mathrm{~W} \mathrm{~kg}^{-1}$.

The general equation for this model allows an approximation of field metabolic rate (FMR, $\mathrm{J} \mathrm{kg}^{-1}$ ) of Humboldt penguins at sea depending on $T_{\text {water }}\left({ }^{\circ} \mathrm{C}\right)$ as well as on the duration of resting $\left(t_{\text {rest }}, \mathrm{s}\right)$ foraging $\left(t_{\text {forage, }} \mathrm{s}\right)$ and travelling $\left(t_{\text {travel }}, \mathrm{s}\right)$ :

$$
\begin{aligned}
\text { FMR }= & 5.95 \times 0.05 \times\left(T_{\mathrm{b}}-T_{\mathrm{a}}\right) \times t_{\text {rest }} \\
& +12 \times t_{\text {travel }}+18.3 \times t_{\text {forage }}
\end{aligned}
$$

where $T_{\mathrm{b}}$ is body temperature $\left({ }^{\circ} \mathrm{C}\right)$, and $T_{\mathrm{a}}$ is ambient or seawater temperature $\left({ }^{\circ} \mathrm{C}\right)$ for temperatures between 22 and $6^{\circ} \mathrm{C}$. $\mathrm{RMR}_{\text {water }}$ is $5.95 \mathrm{~W} \mathrm{~kg}^{-1}$ (at $19^{\circ} \mathrm{C}$ ) and can be converted to other temperatures via $0.05 \times$ $\left(T_{\mathrm{b}}-T_{\mathrm{a}}\right)$.

The main prey of Humboldt penguins is the anchovy, with a mean energy content of $5.93 \mathrm{~kJ} \mathrm{~g}^{-1}$ wet mass (Fitzpatrick et al. 1988). Assuming an assimilation efficiency of penguins feeding on anchovy of $77 \%$ (Guerra 1992), FMR converts to food requirements $(F I, g)$ as:

$$
F I=0.218 \times F M R \times M \times 10^{-3}
$$

where $M$ is penguim body mass $(\mathrm{kg})$.

From these general equations, foraging and migratory costs can be converted to approximate fish requirements if more data on the behaviour of Humboldt penguins at sea become available.

From Luna-Jorquera \& Culik (1999) we know that breeding Humboldt penguins $(M=3.6 \mathrm{~kg})$ foraging around Pan de Azúcar island spend on average $0.8 \pm$ $0.5 \mathrm{~h} \mathrm{~d}^{-1}$ travelling (with mean energetic costs amounting to $124 \mathrm{~kJ}$ ) and $3.7 \pm 2.0 \mathrm{~h}$ foraging (mean energetic cost of $877 \mathrm{~kJ}$ ). Activities at sea therefore add up to $1000 \mathrm{~kJ} \mathrm{~d}^{-1}$. Because the birds spend on average $7.2 \mathrm{~h}$ $\mathrm{d}^{-1}$ resting at the surface, this yields additional energetic demands of $555 \mathrm{~kJ} \mathrm{~d}^{-1}$ (at $T_{\text {water }}=19^{\circ} \mathrm{C}$ ) and the energy used during a foraging trip amounts to a total of $1555 \mathrm{~kJ} \mathrm{~d}^{-1}$.

From Eq. (6), a single breeding Humboldt penguin must therefore consume ca $340 \mathrm{~g}$ anchovies $\mathrm{d}^{-1}$ just to balance its foraging costs at sea. For the penguin population of Pan de Azúcar Island (1750 ind.), this amounts to foraging costs of ca $600 \mathrm{~kg}$ anchovies $\mathrm{d}^{-1}$, to which other costs, such as incubation, resting on land and chick feeding, have to be added. Behavioural data recorded on Humboldt penguins during weak (Culik \& Luna-Jorquera 1997b) and strong (Culik et al. 2000) El Niño events suggests, however, that these demands at times exceed food availability, leading to breeding failure and emigration of the birds.

Acknowledgements. This work was made possible through grants by the Deutsche Forschungsgemeinschaft, Bonn, Germany, to B.M.C. (Cu 24/3 1-3), and by the Deutscher Akademischer Austauschdienst (DAAD), Bonn, to G.L.-J. The Corporación Nacional Forestal, Copiapó, provided kind permission to conduct the experiments on 3 Humboldt penguins from Pan de Azúcar National Park. We are particularly grateful to P. Bethge and N. Böttchers, who travelled to Chile to help us with the swim channel. Dirk Allers helped us with the analysis of the data. We thank Rory Wilson for helpful suggestions and ideas in the initial stage of manuscript pre- 
paration. Carlos Guena and the Instituto de Investigaciones Oceanológicas, Universidad de Antofagasta, provided laboratory space, the pen in which the penguins were housed and an experimental pool, where the swim channel was installed.

\section{LITERATURE CITED}

Allers D, Culik BM (1997) Energy requirements of beavers (Castor canadensis) swimming underwater. Physiol Zool 70:456-463

Bethge P, Nicol S, Culik BM, Wilson RP (1997) Diving behaviour and energetics in breeding Little penguins (Eudyptula minor). J Zool Soc Lond 242:483-502

Butler PJ, Woakes AJ (1984) Heart rate and aerobic metabolism in Humboldt penguins, Spheniscus humboldti, during voluntary dives. J Exp Biol 108:419-428

Castellini MA, Kooyman GL, Ponganis PJ (1992) Metabolic rates of freely diving Weddell seals: correlations with oxygen stores, swim velocity and diving duration. J Exp Biol 165:181-194

Culik BM, Luna-Jorquera G (1997a) The Humboldt Spheniscus humboldti penguin: a migratory bird? J Ornithol 138: 325-330

Culik BM, Luna-Jorquera G (1997b) Satellite tracking of Humboldt penguins (Spheniscus humboldti) in northern Chile. Mar Biol 128:547-556

Culik B, Wilson RP (1991) Energetics of under-water swimming in Adélie penguins (Pygoscelis adeliae). J Comp Physiol B 161:285-291

Culik B, Woakes AJ, Adelung D, Wilson RP, Coria NR, Spairani HJ (1990) Energy requirements of Adélie penguin (Pygoscelis adeliae) chicks. J Comp Physiol B 160: 61-70

Culik BM, Wilson RP, Bannasch R (1994a) Underwater swimming at low energetics cost by pygoscelid penguins. J Exp Biol 197:65-78

Culik B, Bannasch R, Wilson RP (1994b) External devices on penguins: how important is shape? Mar Biol 118:353-357

Culik BM, Pütz K, Wilson RP, Allers D, Lage J, Bost CA, Le Maho Y (1996) Diving energetics in king penguins (Aptenodytes patagonicus). J Exp Biol 199:973-983

Culik BM, Luna-Jorquera G, Oyarzo H, Correa H (1998) Humboldt penguins monitored via VHF telemetry. Mar Ecol Prog Ser 162:279-286

Culik BM, Hennicke J, Martin T (2000) Humboldt penguins outmanoeuvring El Niño. J Exp Biol 203:2311-2322

Drent RH, Stonehouse B (1971) Thermoregulatory responses of the Peruvian penguin, Spheniscus humboldti. Comp Biochem Physiol 40:698-710

Eckert R (1993) Tierphysiologie, 2nd edn. Georg Thieme Verlag, Stuttgart

Ellis S, Croxall JP, Cooper J (1998) Penguin conservation assessment and management plan. Report, IUCN/SSC Conservation Breeding Specialist Group, Apple Valley, MN

Fitzpatrick LC, Guerra C, Aguilar R (1988) Energetics of reproduction in the desert nesting sea gull Larus modestus. Estud Oceanol 7:33-39

Gentry RL, Kooyman GL (1986) Fur seals: maternal strategies on land and at sea. Princeton University Press, Princeton, NJ

Guerra C (1992) Efectos de la nidificación estival/invernal sobre parámetros seleccionados de la historia de vida del

Editorial responsibility: Otto Kinne (Editor),

Oldendorf/Luhe, Germany pingüino de Humboldt Spheniscus humboldti. Proyecto FONDECYT Report 90-0599, Santiago, Chile

Hind AT, Gurney WSC (1997) The metabolic cost of swimming in marine homeotherms. J Exp Biol 200:531-541

Horning M (1992) Die Onthogenese des Tauchverhaltens beim Galapagos Seebären Arctocephalus galapagoensis. Dissertation, Universität Bielefeld

Hui CA (1988) Penguin swimming. II. Energetics and behavior. Physiol Zool 61(4):344-350

Kooyman GL (1989) Diverse divers. Springer Verlag, Berlin

Liss PS, Merlivat L (1986) Air-sea gas exchange rates: introduction and synthesis. In: Buat-Ménard P (ed) The role of air-sea exchange in geochemical cycling. D Reidel Publishing Co, Dordrecht

Luna-Jorquera G (1997) Balancing the energy budget for a warm-blooded bird in a hot desert and cold seas: the case of the Humboldt penguin. Dissertation, ChristianAlbrechts-Universität, Kiel

Luna-Jorquera G, Culik BM (1999) Diving behaviour of Humboldt penguins (Spheniscus humboldti) in northern Chile. Mar Ornithol 27:67-76

Luna-Jorquera G, Culik BM, Aguilar R (1996) Capturing Humboldt penguins Spheniscus humboldti with the use of an anaesthetic. Mar Ornithol 24:47-50

Luna-Jorquera G, Wilson RP, Culik BM, Aguilar R, Guerra C (1997) Observations on the thermal conductance of Adélie (Pygoscelis adeliae) and Humboldt (Spheniscus humboldti) penguins. Polar Biol 17:69-73

Nagy KA, Siegfried WR, Wilson RP (1984) Energy utilization by free-ranging jackass penguins, Spheniscus demersus. Ecology 65:1648-1655

Oehme H, Bannasch R (1989) Energetics of locomotion in penguins. In: Wieser W, Gnaiger E (eds) Energy transformation in cell and organisms. Thieme Verlag, Stuttgart, p 230-240

Schmidt-Nielsen K (1993) Animal physiology: adaptation and environment, 4th edn. Cambridge University Press, Cambridge

Stahel CD, Nicol SC (1982) Temperature regulation in the Little penguins, Eudyptula minor, in air and water. J Comp Physiol 148:93-100

Videler JJ, Nolet BA (1990) Cost of swimming measured at optimum speed: scale effects, differences between swimming styles, taxonomic groups and submerged and surface swimming. Comp Biochem Physiol 97A:91-99

Williams TM (1989) Swimming by sea otters: adaptations for low energetic cost locomotion. J Comp Physiol A 164: 815-824

Wilson RP (1995) Foraging ecology. In: J Williams (ed) The penguins Spheniscidae. Bird families of the World. Oxford University Press, Oxford, p 81-106

Wilson RP, Grémillet D (1996) Body temperatures of freeliving African penguins (Spheniscus demersus) and bank cormorants (Phalacrocorax neglectus). J Exp Biol 199: 2215-2223

Withers PC (1977) Measurement of $\mathrm{VO}_{2}, \mathrm{VCO}_{2}$ and evaporative water loss with a flow-through mask. J Appl Physiol 42:120-123

Woakes AJ, Butler PJ (1983) Swimming and diving in tufted ducks Aythia fuligula, with particular reference to heart rate and gas exchange. J Exp Biol 107:311-329

Zar JH (1984) Biostatistical analysis, 2nd edn. Prentice-Hall, Inc, Englewoods Cliffs, NJ

Submitted: November 12, 1999; Accepted: February 1, 2000 Proofs received from author(s): August 29, 2000 